\title{
Physical therapy evaluation in the immediate post-operative period of patients with lower limbs amputation assisted at the hospital bedside
}

\section{Avaliação fisioterapêutica no pós-operatório imediato do paciente amputado de membros inferiores atendido à beira do leito hospitalar}

\author{
Tuane Sarmento $^{\mathrm{a}}$ (D), Soraia Cristina Tonon da Luz ${ }^{\mathrm{a}}$ (D), Elaine Ferreira de Oliveira ${ }^{\mathrm{a}}$ (D) \\ ${ }^{a}$ Universidade do Estado de Santa Catarina - UDESC, Florianópolis, SC, Brasil.
}

How to cite: Sarmento, T., Luz, S. C. T., \& Oliveira, E. F. (2021). Physical therapy evaluation in the immediate post-operative period of patients with lower limbs amputation assisted at the hospital bedside. Cadernos Brasileiros de Terapia Ocupacional, 29, e2884. https://doi.org/10.1590/2526-8910.ctoAO2179

\begin{abstract}
Lower limb (LL) amputation compromises the individual's quality of life and functionality, requiring immediate rehabilitation through the assistance of a multiprofessional team. This research describes the sociodemographic and physicalfunctional profile of the LL amputee, evaluated at the hospital bedside in the immediate postoperative period. This is a descriptive and cross-sectional study in which patients from the Unified Health System were evaluated, who underwent LL of any etiology in a public hospital. The collection was designated through notifications from the hospital staff regarding cases of newly amputees, totaling fourteen subjects. The average age of the participants was 44 years old, being $86 \%$ male. The etiology of the predominant amputation was automobile trauma due to motorcycle accidents and transtibial level. From the perimetry, it was found that $43 \%$ of the individuals presented edema in the stump when compared to the contralateral limb. Regarding stump pain, $93 \%$ of subjects reported feeling, while $78 \%$ reported feeling phantom pain and phantom sensation. Concerning normal muscle strength in the amputated limb, it was present in only $1 \%$ of patients, in contrast to the intact limb was present in $48 \%$ of individuals for any muscle group. In bed mobility, $32 \%$ of individuals had complete independence. In unipodal orthostatism, no patient was able to stand independently. From the collected data it was possible to conclude that the physical therapist should pay attention to the muscular strength, bed mobility, and static balance of the amputee to avoid muscle contractures and facilitate prosthesis.
\end{abstract}

Keywords: Amputation, Lower Limb, Postoperative Period, Hospital Physical Therapy Department. 


\begin{abstract}
$\underline{\text { Resumo }}$
A amputação de membro inferior (MI) compromete a qualidade de vida e a funcionalidade do indivíduo, necessitando de reabilitação imediata com auxílio de equipe multiprofissional. Esta pesquisa teve como objetivo descrever o perfil sociodemográfico e físico-funcional do amputado de MI, avaliado à beira do leito hospitalar no pós-operatório imediato. Trata-se de um estudo descritivo e transversal, avaliados pacientes do Sistema Único de Saúde, submetidos à amputação de MI de qualquer etiologia em um hospital público. A coleta ocorreu através de notificaçóes da equipe do hospital sobre os casos de recém-amputados, totalizando quatorze sujeitos. A idade média dos participantes foi de 44 anos, sendo $86 \%$ do sexo masculino. A etiologia da amputação predominante foi trauma automobilístico por acidente de motocicleta e nível transtibial. Pela perimetria constatou-se que $43 \%$ dos indivíduos apresentavam edema no coto quando comparado ao contralateral. Em relação à dor no coto, 93\% dos sujeitos relataram sentir, enquanto $78 \%$ relataram sentir dor fantasma e sensação fantasma. Em relação à força muscular normal no membro amputado, esta esteve presente em apenas $1 \%$ dos pacientes, ao passo que o membro intacto esteve presente em $48 \%$ dos indivíduos para qualquer grupo muscular. Na mobilidade no leito, $32 \%$ dos indivíduos apresentaram independência completa. No ortostatismo unipodal nenhum paciente foi capaz de ficar em pé de forma independente. A partir dos dados coletados concluiu-se que o fisioterapeuta deve estar atento à força muscular, mobilidade na cama e equilíbrio estático do amputado, a fim de evitar contraturas musculares e facilitar a prótese.
\end{abstract}

Palavras-chave: Amputação, Membro Inferior, Pós-operatório, Serviço de Fisioterapia Hospitalar.

\title{
Introduction
}

Amputation is by definition the partial or total removal of a body segment, performed surgically in order to treat certain pathologies (Brasil, 2012). The most recurrent amputation level is transtibial, followed by knee disarticulation and transfemural level (Araujo \& Carvalho, 2017). Lower limb (LL) amputation compromises the individual's quality of life and functionality, requiring immediate rehabilitation through assistance composed of a multidisciplinary team (Almeida et al., 2017).

According to data from DATASUS, in the first half of 2018 (January to June), there were 12.367 new cases of lower limb amputations in Brazil. In the same period of time, in the southern region, there were 1.681, and in the state of Santa Catarina 412 cases (Departamento de Informática do Sistema Único de Saúde, 2018). The high recurrence presented in such data demonstrates the relevance of producing knowledge about the theme of lower limb amputations, which is a global public health problem (Brasil, 2012).

Regardless of the etiology of the amputation, the person undergoing this procedure needs to be thoroughly evaluated. This evaluation should contain the main physical dysfunctions of the individual so that it can be directed to an early 
physical therapy rehabilitation. The purpose of the previous physical therapy intervention extends from the postoperative period until prosthesis, allowing the independence of the amputee and, consequently, the social and professional reintegration (Neves, 2017).

Among the main recurring consequences of an amputation there is the occurrence of phantom pain, defined as a painful spatial sensibility controlled by means of the brain stem and limbic system (Estevão et al., 2020; Ticianelli et al., 2003). The phantom sensation, however, is the absence of pain, but with the appearance of sensations in the limb that no longer exists. Stump pain, on the other hand, can be defined as local pain where the amputation occurred, that is, the residual limb (Araujo \& Carvalho, 2017; Nikolajsen \& Jesen, 2001).

The healthcare professional in charge of evaluating the amputee should consider the importance of his or her initial approach and realize that the patient carries an intense emotional burden, resulting from the grief process experienced through anxiety, low self-esteem, future insecurity, disharmonious social relations, as well as the possibility of professional inactivity (Campos et al., 2018; Teixeira \& Novak, 2009). For the proposed treatment to be efficient it's extremely important that such issues are not neglected (Magee, 2010).

The specific physical therapy evaluation of the lower limb amputee and the reception in the hospital environment, at this moment, are indispensable for the person to feel protected, accepted, understood and to be able to trace new life projects. The interdisciplinary team is able to provide the amputee patient with correct direction to physical therapy, thus promoting an early and effective rehabilitation (Santos et al., 2018). It's also noteworthy the occupational therapist is essential to promote quality of life for patients, encouraging functional independence, making possible an adapted return to their usual activities (Salinas, 2018; Villacrosa, 2008).

As an early rehabilitation strategy, Amputee Multidisciplinary Rehabilitation Project (RAMP) of the Santa Catarina State University (UDESC) branched out into the hospital environment. Such intervention strategy occurred due to recurrent episodes of late arrival of amputees to the extension project, making the rehabilitation process negative. The lack of intervention and/or early guidance generate dysfunctions such as muscle contractures, decreased range of motion, muscle weakness, and consequently restrict the success of rehabilitation and the possibility of prosthesis.

Considering the urgency regarding the immediate postoperative (PO) period of the individual who underwent amputation surgery, it was realized the need to apply a specific evaluation instrument to the patient recently amputated at the hospital bedside. The use of the instrument allows the characterization of the sociodemographic profile, physical dysfunctions, mobility limitations, static balance changes, so that it's possible to determine an individualized physical therapy care plan (Santos, 2014). Upon obtaining the traced profile, it'll be possible to early rehabilitate the amputated patient, through appropriate guidance from health care professionals. Thus, this study's aim is to describe the sociodemographic and physical-functional profile of the lower limb amputee evaluated at the hospital bedside in the immediate postoperative period. 


\section{Method}

\section{Study design}

This study is part of the umbrella project entitled "Health promotion of amputees in the hospital environment" belonging to the Amputee Multidisciplinary Rehabilitation Extension Project - RAMP of the Center of Health and Sport Sciences (CEFID) of UDESC (Santos, 2014).

This is a cross-sectional and descriptive study, performed at the orthopedics department of the Hospital Regional de São José Dr. Homero de Miranda Gomes (HRSJHMG) and at the headquarters of the Cardiology Institute of Santa Catarina (ICSC), located in the same hospital.

\section{Study site}

It's important to highlight that the hospital in which the collections were performed is a reference in amputation surgery in Greater Florianópolis, Santa Catarina State, Brazil.

\section{Ethics procedure}

This work was approved by the ethics committees: UDESC $\mathrm{n}^{\circ}$ 33009514.9.3001.0112 and Hospital no 33009514.9.3001.0112. All study participants agreed and signed the Informed Consent Form (ICF).

\section{Data collection procedure}

The collection occurred from May 2017 to September 2018. The time of application of the form after surgery ranged from 24 to 72 hours, characterizing the sample as a mediate PO. Inclusion criteria were: hospitalized subjects; age over eighteen years old; in the postoperative period; submitted to lower limb amputation of any etiology. The exclusion criteria applied were: individuals with cognitive impairment, refusal of informed consent form and lack of time between notification and patient discharge.

\section{Sample}

Twenty individuals who underwent an amputation were notified by the hospital. However, six patients were excluded due to established criteria (refusal to sign the informed consent form, cognitive impairment or short time between hospital notification and patient discharge). In total, fourteen received an amputation selected according to the specified criteria were included in this study.

\section{Instruments}

In the first approach, the reception of the amputated individual, proposed by RAMP, was promoted. The project provides intersectoral actions for the reception of individuals who underwent an amputation based on the Amputee Attention Guideline 
(Brasil, 2012), through hospital notification. The reception was characterized by conversation in bed; delivery of a bag-shaped project bed kit containing: a health care guide for the amputees, a project information folder, an elastic band for stump bandage and a scheduling card for first consultation in the extension project.

After the reception and delivery of the kit, the specific physical therapy evaluation of the amputee began, with an average duration of 50 minutes. A hospital physical therapy evaluation form developed by UDESC RAMP project was used, consisting of the respective items: personal data; anthropometric evaluation: height and body mass, calculating BMI (World Health Organization, 1995); cause of amputation; associated pathologies; vital signs; static cardiorespiratory evaluation: cyanosis, cough, chest pain, chest type, edema, locker sign and dynamic: respiratory type, rhythm, use of accessory muscles, signs of respiratory distress, dyspnea evaluation using the BORG scale (Borg, 1980); bed inspection and palpation; amputation level; measurement of stump pain by visual analog scale (VAS), golden standard to the pain's evaluation (Jensen \& Karoly, 1992); presence or not of phantom pain and sensation; perimeter and body circumference (edema differences above $2 \mathrm{~cm}$ were considered comparing the lower limbs - Schulze et al., 2006); muscle strength through Kendall validity scale (Kendall $\&$ Mccreary, 1987); motor activities in bed; static balance by sedestation; and unipodal orthostatism.

\section{Statistical analysis}

Data were treated using descriptive statistics using the Statistical Package for Social Science (SPSS) statistical program, version 21.0 and the significance level was $\alpha=0.05$.

\section{Results}

Of the fourteen subjects evaluated, twelve were male. The average age of the participants was 44 years old ( \pm 19 years), being the predominant age group of six adults, followed by four elderly, three middle age and one young individual, classified in age groups according to Silva (2004). Regarding the city of residence of Greater Florianópolis, there was a predominance of residents of São José city, totaling seven subjects, followed by Palhoça with five people and in the cities of Apiúna and Major Gercino with one individual from each location.

Regarding self-reported ethnicity, of the fourteen patients evaluated, nine were caucasian, three were brown and two were black. With regard to marital status, five subjects were married, four single, three living together, one divorced and one widower. Relating to education, six individuals declared incomplete high school, three individuals had completed elementary school, three individuals indicated incomplete elementary school, followed by two individuals with completed high school. In regard to occupation, nine patients had jobs, being three bricklayers, three retirees, one student and one unemployed.

With reference to body mass index, it was observed the presence of five individuals with overweight or obesity grade I and the other participants were classified with normal index. Concerning the etiology of amputation, motor vehicle trauma caused by motorcycle accident was the majority, totaling ten individuals in the sample, followed 
by four vascular diseases (two due to diabetes mellitus and two due to arterial thrombosis). The four individuals who underwent an amputation due to vascular disease were elderly individuals, with a mean age of 67.7 years old ( \pm 5 years).

In respect of the level of amputation of the lower limb, nine individuals were transtibial and five transfemoral, with seven subjects amputated in the right lower limb, six in the left lower limb and one bilateral individual. Eight subjects had the following associated pathologies: systemic arterial hypertension, diabetes mellitus (DM), dyslipidemia, congenital hip dislocation, aortic laceration, anemia, deep vein thrombosis or necrolysis.

Vital signs were classified as unstable for four evaluated individuals: systolic blood pressure greater than $160 \mathrm{mmHg}$; heart rate greater than $100 \mathrm{bpm}$ or respiratory rate greater than $20 \mathrm{rpm}$. Regarding pulmonary auscultation, nine individuals were altered, that is, decreased vesicular murmur with or without adventitious noises and the others fit within the normal range (present vesicular murmur, without adventitious noises).

In the cardiorespiratory evaluation, no individual had cyanosis and/or dyspnea (evaluated by the BORG scale). Only three individuals had a spontaneous, productive cough, but without impairment during the hospital period. In regard to the type of breathing pattern, seven hospitalized patients revealed mixed classification, followed by five abdominal and two apical, and of these, nine used accessory muscles. Concerning smoking dependence, four of the fourteen participants were smokers.

With reference to the type of chest, ten individuals had the normolineal chest, three had pectus excavatum and one had the barrel chest. Only two individuals had altered respiratory rhythm and reports of chest pain, while signs of respiratory distress were observed in six patients.

Of the fourteen patients, eight presented edema measured by perimetry (wrist, lower limb or ankle), and six with positive locker sign. Nine individuals with alteration in the contralateral limb (superficial lesions, swollen, hypotrophic or cyanotic) and nine individuals with upper limb alteration (superficial lesions, swollen, hypotrophic or cyanotic) were found.

Regardless the amputation level, all individuals presented the quadrilateral shape stump due to the bandage used to bandage the stump performed by the hospital's nursing service. Regarding phantom pain and phantom sensation, $78 \%$ of patients reported feeling pain at the time of the evaluation. Stump pain was also present in $93 \%$ of participants at the immediate postoperative period (Figure 1).

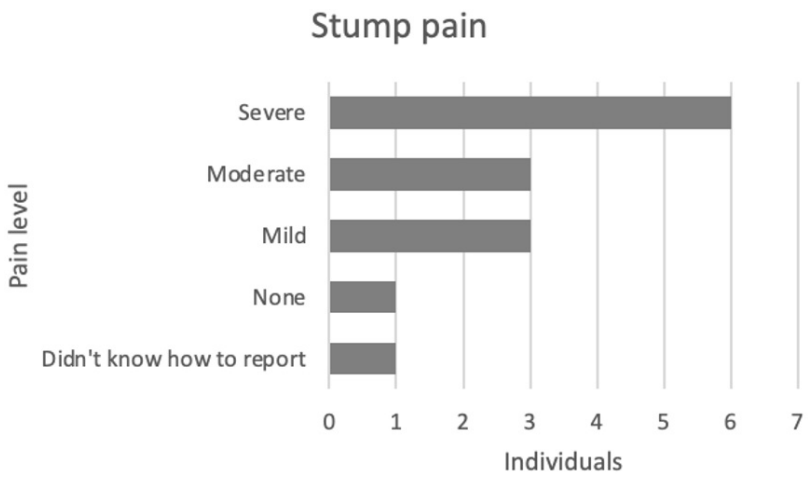

Figure 1. Stump pain intensities (Visual Analog Scale - VAS). Source: Author's own elaboration. 
The findings showed that six individuals underwent associated surgeries, five of them for fractures (polytrauma). Of the fourteen patients, two needed external fixation and three used plates or pins.

Of the fourteen individuals collected, only three needed some type of drain or tube (chest, abdominal cavity or bladder), highlighting that one patient required colorraphy and/or had contralateral lower limb wounds. Regarding graft application, it was necessary in two patients. Only one individual had left calcaneal pressure injury and no individual had traumatic brain injury.

The evaluation of bed mobility was performed through active bed transfers, and the patient was encouraged to perform transfers according to their tolerance (Table 1). Static equilibrium was also evaluated through sedestation and unipodal orthostatism. The following data were found, described in Table 1:

Table 1. Bed mobility and static balance activities.

\begin{tabular}{ccccc}
\hline Specific Activity & Independent \% (n) & $\begin{array}{c}\text { With aid \% } \\
(\mathbf{n})\end{array}$ & $\begin{array}{c}\text { Does not } \\
\text { perform \% (n) }\end{array}$ & $\begin{array}{c}\text { Not applicable \% } \\
(\mathbf{n})\end{array}$ \\
\hline Bridge & $50 \%(7)$ & $7.14 \%(1)$ & $14.28 \%(2)$ & $28.57 \%(4)$ \\
\hline $\begin{array}{c}\text { Supine to Right lateral } \\
\text { decubitus }\end{array}$ & $42.85 \%(6)$ & $14.28 \%(2)$ & $21.42 \%(3)$ & $21.42 \%(3)$ \\
\hline $\begin{array}{c}\text { Supine to Left lateral } \\
\text { decubitus }\end{array}$ & $28.57 \%(4)$ & $7.14 \%(1)$ & $28.57 \%(4)$ & $35.71 \%(5)$ \\
\hline $\begin{array}{c}\text { Lateral decubitus to } \\
\text { sitting }\end{array}$ & $35.71 \%(5)$ & $28.57 \%(4)$ & $14.28 \%(2)$ & $21.42 \%(3)$ \\
\hline Sitting to standing & $21.42 \%(3)$ & $35.71 \%(5)$ & $14.28 \%(2)$ & $28.57 \%(4)$ \\
\hline Sedestation & $21.42 \%(3)$ & $42.85 \%(6)$ & $28.57 \%(4)$ & $7.14 \%(1)$ \\
\hline Unipodal orthostatism & $0 \%(0)$ & $57.14 \%(8)$ & $21.42 \%(3)$ & $21.42 \%(3)$ \\
\hline
\end{tabular}

Source: Author's own elaboration.

In this study, the actual length of the lower limbs was also evaluated using a tape measure and anatomically measured from the anterior superior iliac crest to the medial malleolus. Figure 2 shows the percentage of anatomical loss, in which $71,4 \%$ of the individuals lost less than half of the limb due to amputation when compared to the contralateral limb, adding up to 13 individuals. This data reveals a more conservative surgical profile, since there was a greater preservation of the amputated limb as possible. Only one patient was bilateral amputee, making it possible to measure the actual length of the lower limb.

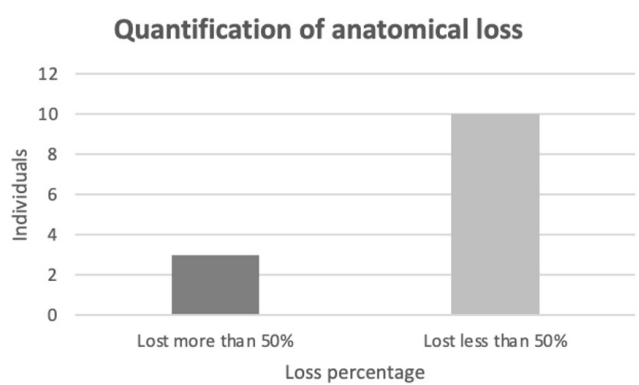

Figure 2. Quantification of anatomical loss of the amputated limb when compared to the contralateral limb. Source: Author's own elaboration. 
Another instrument used as part of the evaluation was the perimeter of the amputated and contralateral limb, through the tape measure with the demarcated anatomical points, starting from the anterior superior iliac spine, using a dermographic pen delimiting them in centimeters until reaching the stump, all individuals had bandages on the stump at the time of evaluation. In this work was possible to perform the perimetry in six individuals, in the rest it wasn't possible due to the guidance to keep the amputated limb immobilized. It was verified that $43 \%$ of the individuals had edema in the stump when compared to the contralateral limb.

Regarding the maximal muscle strength for the intact limb, for the flexor, extensor, adductor, external and internal hip rotator and knee flexor muscle groups, $35 \%$ of the individuals were able to perform the 5th degree strength. In the hip abductors, $42 \%$ of the individuals reached maximal strength, while in knee extensors and dorsiflexor muscles, $50 \%$ of patients were able to. Plantiflexor muscle strength was the highest, totaling $64 \%$ of individuals. In the amputated limb, only $1 \%$ of the patients had maximum muscle strength for any of the previously described muscle groups.

\section{Discussion}

The HRSJHMG is a reference in traumatology and orthopedics in the state of Santa Catarina and also headquarters of the ICSC. The largest number of notifications received for the application of the evaluation form of this study came from the orthopedics and traumatology department of the referred hospital, totaling $78,5 \%$ of the sample, the remaining $21,5 \%$ were notified by the ICSC. In this research, there was a higher incidence of individuals residing in São José, corroborating the location of the hospital.

In agreement with the literature (Lima et al., 2016; Fernandes et al., 2015), the data reveal that the majority of the sample was represented by males, average age of 44 years old and etiology of amputation due to motor vehicle accident. In the study by Fernandes et al. (2015), with a sample of 241 motorcycle accident victims, $79 \%$ injured individuals were male. When comparing means of transportation, motorcyclists are more likely to be injured (Chang \& Yeh, 2006) and once an individual has a motorcycle accident, it takes between one and six months to fully recover (Fernandes et al., 2015).

In contrast, according to Fiore et al. (2015) vascular diseases are the main causes of lower limb amputation, as they affect more than half of the total number of amputees. However, in this study, $14 \%$ of amputation due to DM and $14 \%$ to arterial thrombosis were found, accounting for only $28 \%$ in the etiology of vascular diseases, reported by the ICSC. According to the Brazilian Society of Angiology and Vascular Surgery São Paulo regional, vascular diseases are considered as chronic venous insufficiency, arterial thrombosis, deep vein thrombosis, diabetic foot, carotid artery disease, peripheral obstructive arterial disease and abdominal aortic aneurysm. In the literature, vascular amputation is more recurrent; however, in this study, $71 \%$ of individuals amputated due to traumatic causes. Traumatic amputation depends on the trauma mechanism, ischemic time, comorbidities with high risk of secondary amputation (advanced age, associated comorbidities, etc.), as well as functional recovery conditions (Senefonte et al., 2012). 
Corroborating this study, Tavares et al. (2009) regarding marital status found that $50,7 \%$ of their sample were married or living with their partner. In a survey by Awori \& Ating'a (2007) conducted in Kenya, the education where the highest incidence of amputations occurs was in individuals with low education, represented in the study by $89,1 \%$. In contrast, in this study most individuals had incomplete high school, totaling $42,8 \%$ of the sample. Still in the study by Awori and A'tinga in which the average age of the sample corroborates this study ( 44,8 years old) pointed out that $55,4 \%$ of the subjects were unemployed, followed by $39 \%$ working without a formal contract. In contrast, our findings highlight that $64 \%$ of individuals were workers with a formal contract. It's noteworthy that there are policies and guidelines that assure the individual's right to return to work and accessibility, but lower limb amputees have difficulties in practice with access to furniture and urban transport (Associação Brasileira de Normas Técnicas, 2004; Brasil, 2013; Brasil, 2016; Campos et al., 2018).

In a study by Silva (2017) with 113 individuals in the state of Bahia, investigated risk factors for diabetic foot, found ethnicity as one of the factors, with the highest incidence of self-declared brown individuals, comprising $50 \%$ of the sample. In the current study the same did not occur, because $64 \%$ of the sample self-declared caucasian, this higher incidence can be justified due to the location where the current research occurs, characterized by individuals from southern Brazil.

Several changes in the body occur during the postoperative period through tissue effects arising from surgical stress (Miranda et al., 2011). Correlated with these effects are vital signs, which objectively reflect the situation of the individual's functional physical state of health. Vital signs may be unstable from changes in blood pressure, respiratory and heart rate, and body temperature (Chaves, 2004). In this study it was found that only $28,5 \%$ of the individuals presented alteration in any of the vital signs cited.

In this study it was found that $42,8 \%$ of the individuals had stump edema when compared to the contralateral limb. Corroborate this study, Novais et al. (2018) emphasizes that the most common comorbidities found in the sample were diabetes mellitus, hypertension and smoking.

According to Ekstein \& Weinbroum (2011), severe permanent pain in the PO is predicted. The intensity of pain in bones and joints is significantly more painful than the pain found in the report of individuals by trauma to the abdominal viscera, for example. In agreement with the findings of this study, Tubbs et al. (2015) describes that, phantom pain in the amputated limb occurs in $85 \%$ of cases. Over the years there may be a decrease in the intensity and frequency of phantom pain, however, the study reveals that from 5 to $10 \%$ of amputees still have severe phantom limb pain after years which is often a chronic pathology that's difficult to treat.

According to Araujo \& Carvalho (2017) and Pinto et al. (1998) the amputation with higher incidence is transtibial level, being more functional for the prosthesis phase. This level of amputation occurs most often because it aims to conserve most of a viable gastrocnemius muscle-tendon structure. Therefore, the intended amputation level is as distal as possible, taking into account the specific clinical picture of each patient, corroborating this study.

A study by Teixeira \& Novak (2009) with a sample of 17 lower limb amputees revealed that in relation to bed mobility in the outpatient setting, $64,7 \%$ of individuals 
had complete autonomy. Whereas this study achieved only $32 \%$ independence in bed. This difference may be associated with the immediate PO period that this study brought.

In the amputated limb, normal muscle strength was present in only $1 \%$ of patients. Regarding unipodal orthostatism, no patient was able to stand independently. In a study by Nolan (2012) with a sample of 16 individuals to promote increased muscle strength of hip flexors and extensors, the following intervention was performed: warm-up, strengthening, balance and aerobic exercises. The outcome was positive, obtained significant gain in muscle strength.

In the hospital environment, guidance should be given on how to perform posture transfers, proper use of auxiliary devices and stump positioning. The patient should also be treated for stump and phantom pain (Santos et al., 2018). According to Vieira et al. (2017), an interdisciplinary team from the moment of the postoperative period is important so that it's possible to return to activities such as leisure, work and daily life as early as possible (Brasil, 2012).

At the hospital where the collection was performed, the physical therapy service is offered to the amputee and part of the notifications promoted were by physical therapy professionals. During this period, physical therapy becomes indispensable to intervene with, for example, correct bed positioning, active-assisted, active-free and isometric exercises, use of bandages, proprioception exercises, contralateral and upper limb work and gait training. (Signorelli et al., 2003). It's noteworthy that other conducts can also be performed according to the patient's need, observing him holistically or globally.

\section{Study limitations}

Due to the hospital routine and the clinical condition of certain patients, some were discharged between 24 and 48 hours, so it wasn't possible to move in time for physical therapy evaluation in bed. It also wasn't possible to evaluate the range of motion by means of goniometry, due to the duration of the 50 minute care, pre-established by the ethics committee, which aims to provide care without stressing the patient. It was impossible to verify the drugs used by all patients, as well as the complementary exams due to hospital routine (availability of computers and/or medical records for access to information at the time of intervention). It wasn't possible to evaluate stump healing aspects, since the stump remained with bandages, through nursing care that didn't coincide with the moment of the evaluation. Regarding perimetry, it was also not possible to evaluate in all individuals, because the stump had to remain immobilized due to cases of fracture. Despite 16 months of collection, the small sample size is also a limitation.

\section{Final considerations}

This study reveals its importance to the multidisciplinary hospital team that deals with amputees, exposing a particular physiotherapeutic evaluation form to the patient who underwent a lower limb amputation, thus obtaining the dimension of the sociodemographic profile, as well as the physical-functional data. In the sociodemographic profile, it can be concluded that the male public, drivers of 
motorcycles, working profile, in their 40s are at greater risk of suffering a transtibial lower limb amputation. In the physical-functional data, the immediate PO period has as main complications the edema and stump pain, decreased muscle strength, decreased bed mobility, changes in vital signs, as well as pain and phantom sensation.

These findings are important for the performance of specific and individualized procedures for lower limb amputee patients. The physical therapy professional has the challenge of gaining or maintaining muscle strength, mobility in the bed, and promoting the static balance of the amputee, in order to avoid muscle contractures, facilitating the prosthesis phase. From a welcoming approach, it was also possible for the amputee to have the clarification of their current health status, providing selfperception of their physical abilities. Through the outlined patient profile, it's viable to promote early rehabilitation, since the first guidelines on the process via health system will be carried out to achieve the prosthesis and resolve uncertainty, performed immediately in the hospital environment.

\section{Reference}

Almeida, A. E. C., Carvalho, A. C., Braga, J. J., Carvalho, M. M. B., \& Vasconcelos, T. B. (2017). Elaboração de uma ficha de avaliaçáo para amputados de membros inferiores: relato de experiência. Revista de Saúde Pública, 21(2), 207-213.

Araujo, D. M. S., \& Carvalho, D. O. (2017). Qualidade de vida e funcionalidade dos amputados em membros inferiores do Hospital Santa Marcelina (Trabalho de conclusão de curso). Centro Universitário São Lucas, Porto Velho.

Associação Brasileira de Normas Técnicas - ABNT. (2004). NBR 9050: Acessibilidade a edificaçóes, mobiliário, espaços e equipamentos urbanos. Rio de Janeiro: ABNT.

Awori, K. O., \& Ating'a, J. E. (2007). Lower limb amputations at the Kenyatta National Hospital, Nairobi. East African Medical Journal, 84(3), 121-126.

Brasil. (2012). Diretrizes de atenção à pessoa amputada. Brasília: Ministério da Saúde.

Brasil. (2013). Viver sem limite: plano nacional dos direitos da pessoa com deficiência. Brasília: Secretaria Nacional de Promoção dos Direitos da Pessoa com Deficiência (SNPD).

Brasil. (2016). Acidente de trabalho: conheça seus direitos. Brasília: Ministério do Trabalho e da Previdência Social.

Borg, G. A. (1980). Category scale with ratio properties for intermodal and interindividual comparisons. In H. G. Geissler \& P. Petzol (Eds.), Psychophysical judgement and the process of perception (pp. 2534). Amsterdam: North Holland Publishing Co.

Campos, P. V. C., Tonom, L. S. C., \& Sarmento, T. (2018). Barriers and facilitators to return to work experienced for amputees of lower limbs over Brazilian guidelines optics. Cadernos Brasileiros de Terapia Ocupacional, 26(1), 111-118. http://dx.doi.org/10.4322/2526-8910.ctoAO0959.

Chang, H. L., \& Yeh, T. H. (2006). Risk factors to driver fatalities in single-vehicle crashes: Comparisons between non- motorcycle drivers and motorcyclists. Journal of Transportation Engineering, 132(3), 227-236.

Chaves, M. (2004). Dor pós-operatória: aspectos clínicos e assistência de enfermagem. In L. D. Chaves \& E. R. Leão (Orgs.), Dor $5^{\circ}$ sinal Vital: reflexóes e intervençôes de enfermagem (pp. 151-168). São Paulo: Martinari.

Departamento de Informática do Sistema Único de Saúde - DATASUS. (2018). Ministério da Saúde Sistema de Informaçôes Hospitalares do SUS (SIH/SUS). Recuperado em 15 de outubro de 2018, de http://tabnet.datasus.gov.br/cgi/tabcgi.exe?sih/cnv/qiuf.def. 
Ekstein, M. P., \& Weinbroum, A. A. (2011). Immediate postoperative pain in orthopedic patients is more intense and requires more analgesia than in post-laparotomy patients. Pain Medicine, 12(2), 308-313. http://dx.doi.org/10.1111/j.1526-4637.2010.01026.x.

Estevão, M. C., Miranda, C., Pereira, A. P. G. S., Souza, E. N., Pereira, R. S. F., Ribeiro, C. F., \& Melo, A. U. C. (2020). Phantom Pain in patients undergoing amputation: an integrative review. Medicus, 2(2), 1-5. http://dx.doi.org/10.6008/CBPC2674-6484.2020.002.0001.

Fernandes, F. F., Reis, C. C., Câmara, S. M. A., \& Maciel, A. C. C. (2015). Fatores associados ao não retorno ao trabalho de indivíduos acidentados de moto: um estudo epidemiológico. Revista Baiana de Saúde Pública, 39(2), 191. http://dx.doi.org/10.5327/Z0100-0233-2015390200002.

Fiore, A. R., Neto, A. M., Daniel, K. B., Minicucci, J., Wittmann, D. E. Z., Pavin, E. J., Parisi, M. C. R., \& Tambascia, M. A. (2015). Risk factors for ulceration and amputation in patients with diabetic foot at risk: results form a tertiary care center. Diabetology \& Metabolic Syndrome, 7(Suppl. 1), A18. http://dx.doi.org/10.1186/1758-5996-7-S1-A18.

Jensen, M. P., \& Karoly, P. (1992). Self-report scales and procedures for assessing pain in adults. In D.C. Turk \& R. Melzack (Eds.), Handbook of pain assessment (pp. 135-151). New York: The Guilford.

Kendall, F. P., \& Mccreary, E. K. (1987). Músculos: provas e funçôes. Rio de Janeiro: Guanabara Koogan.

Lima, L. B., Correia, V. D., Melo, S., \& Camargo, A. (2016). Perfil social do paciente amputado em processo de reabilitação. Acta Fisiátrica, 23(2), 57-60. http://dx.doi.org/10.5935/01047795.20160012 .

Magee, D. J. (2010). Avaliação Musculoesquelética. São Paulo: Manole.

Miranda, A. F. A., Silva, L. F., Caetano, J. Á., Sousa, A. C., \& Almeida, P. C. (2011). Avaliação da intensidade de dor e sinais vitais no pós-operatório de cirurgia cardíaca. Revista da Escola de Enfermagem da USP, 45(2), 327-333. http://dx.doi.org/10.1590/S0080-62342011000200004.

Neves, M. F. A. (2017). Eficácia da implementação precoce de um programa de reabilitação nos utentes submetidos a amputação do membro inferior no sucesso da protetização (Tese de doutorado). Escola Superior de Saúde de Viseu, Portugal.

Nikolajsen, L., \& Jensen, T. S. (2001). Phantom limb pain. British Journal of Anaesthesia, 87(1), 107-16. http://dx.doi.org/10.1093/bja/87.1.107.

Nolan, L. (2012). A training programme to improve hip strength in persons with lower limb amputation. Journal of Rehabilitation Medicine, 44(3), 241-248. http://dx.doi.org/10.2340/16501977-0921.

Novais, R. B., Barbosa, A. A. L., Intelizano, P. M., Bin, F. C., Castro, K. D. M., Formiga, F. B., Manzione, T. S., \& Batista, C. F. L. (2018). Comparative study between amputation of the rectum in the classic Lloyd-Davies position and in ventral decubitus. Revista do Colégio Brasileiro de Cirurgiōes, 45(5), e1643. http://dx.doi.org/10.1590/0100-6991e-20181643.

Pinto, M. A. G. S., Astir, F. N., Guedes, J. P. B., \& Yamahoka, M. S. O. (1998). Ponte óssea na amputaçäo transtibial. Revista Brasileira de Ortopedia, 33(7), 525-531.

Salinas, J. C. J. (2018). Integral rehabilitation of amputees: a global vision. Chile: RIL Editors.

Santos, K. (2014). Ação de extensão: reabilitação multidisciplinar em amputados. Cidadania em ação: Revista de Extensão e Cultura, 8(1), 176-185.

Santos, B., Luz, S. C. T., Santos, K. B., Honório, G. J. S., \& Farias, G. O. (2018). Atuação de equipe multiprofissional no atendimento à pessoa amputada: contextualizando serviços e protocolos hospitalares. Cadernos Brasileiros de Terapia Ocupacional, 26(3), 527-537. http://dx.doi.org/10.4322/2526-8910.ctoao1193.

Schulze, T., Mucke, J., Markwardt, J., Schlag, P. M., \& Bembenek, A. (2006). Long-term morbidity of patients with early breast cancer after sentinel lymph node biopsy compared to axillary lymph node dissection. Journal of Surgical Oncology, 93(2), 109-119.

Senefonte, F. R. A., Rosa, G. R. P. S., Comparin, L. M., Covre, M. R., Jafar, M. B., Andrade, F. A. M., Maldonado Filho, G., \& Nogueira Neto, E. (2012) Amputação primária no trauma: perfil de um 
hospital da região centro-oeste do Brasil. Jornal Vascular Brasileiro, 11(4), 269-276. https://doi.org/10.1590/S1677-54492012000400004..

Signorelli, M. C., Cancelier, M., Mazzucco, A., \& Kurban, E. (2003). Protocolo para fortalecimento do membro residual através de eletroestimulação neuromuscular com modulação russa em amputados transtibiais proximais. Rev. Reabilitar, 5(18), 40-43.

Silva, N. (2004). Ser adulto: alguns elementos para a discussão deste conceito e para a formação de professores de adultos. Millenium, 2(29), 282-290.

Silva, V. A. M. (2017). Pé diabético: Fatores de risco para amputação. In Anais do Seminário de Iniciação Cientifica. Bahia: UEFS. http://dx.doi.org/10.13102/semic.v0i21.2579.

Tavares, D. M. D. S., Dias, F. A., Araujo, L. R., \& Pereira, G. A. (2009). Perfil de clientes submetidos a amputaçóes relacionadas ao diabetes mellitus. Revista Brasileira de Enfermagem, 62(6), 825-830.

Teixeira, G., \& Novak, V. C. (2009). Nível de independência física dos amputados de membros inferiores do município de Guarapuava - PR. In Anais do $12^{\circ}$ Encontro Latino Americano de Iniciação Cientifica; $9^{\circ}$ Encontro Latino Americano de Pós graduação. São José dos Campos: Universidade do Vale do Paraíba. Recuperado em 13 de outubro de 2018, de http://cronos.univap.br/cd/INIC_2009/anais/arquivos/RE_0643_1065_01.pdf.

Ticianelli, J. G., Baraúna, M. A., \& Silva, A. M. C. (2003). Transcutaneous electrical nerve stimulation effect on phantom pain. Brazilian Journal of Physiotherapy, 7(2), 115-122.

Tubbs, R. S., Rizk, E., Shoja, M. M., Loukas, M., Barbaro, N. M., \& Spinner, R. J. (2015). Nerves and nerve injuries: pain, treatment, injury, disease and future directions. Rio de Janeiro: Academic Press.

Villacrosa, J. A. (2008). Lower limb amputations in vascular surgery: a multidisciplinar problem. Chile: RIL Editors.

Vieira, R., Luz, S. C., Santos, K. P., Junior, E. G., \& Campos, P. V. (2017). Physiotherapeutic interventions used in lower limb amputees before and after prosthesis. Physiatric Acta, 24(2), 98-104. http://dx.doi.org/10.5935/0104-7795.20170019.

World Health Organization - WHO (1995). Expert Committee on Physical Status: the use and interpretation of anthropometry: report of a WHO expert committee. Genebra: WHO.

\section{Contribuição das autoras:}

Tuane Sarmento: Concepção do texto, organização de fontes e/ou análises, redaçáo do texto. Soraia Cristina Tonon da Luz: Revisão. Elaine Ferreira de Oliveira: Concepção do texto, redação do texto e revisão. Todas as autoras aprovaram a versão final do artigo.

\section{Autora para Correspondência}

Tuane Sarmento. Email: tuanesarmento@gmail.com

\section{Editor de seçáo}

Prof. Dr. Daniel Marinho Cezar da Cruz 